
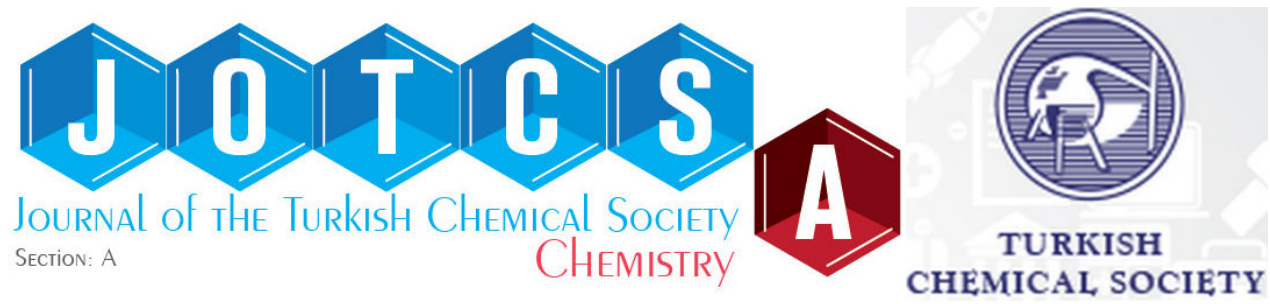

\title{
Synthesis, Cytotoxicity, and Molecular Docking Study of Complexes Containing Thiazole Moiety
}

\author{
Mohammed Shafeeulla $\mathrm{R}^{1}$, Ganganaik Krishnamurthy ${ }^{1 *}$,Halehatti S. Bhojynaik ${ }^{2}$, Manjuraj $\mathrm{T}^{2}$ \\ ${ }^{1}$ Department of Chemistry, Sahyadri Science College (Auto), Shimoga, Karnataka (INDIA). \\ 2Department of Industrial Chemistry, Janna Sahyadri, Kuvempu University, Shankaraghattha, \\ Karnataka (INDIA).
}

\begin{abstract}
The ligand 5-methyl-2-phenyl-4-[(E)-1,3-thiazol-2-yl-diazenyl]-2,4-dihydro-3Hpyrazol-3-one (Dy) has been synthesized by diazo coupling reactions of 5-methyl-2-phenyl-2,4dihydro-3H-pyrazol-3-one with 2-aminothiazole and ferric hydrogen sulfate (FHS), as a catalyst, under solvent-free conditions. A series of complexes of the ligand with $\mathrm{Co}$ (II), $\mathrm{Ni}(\mathrm{II}), \mathrm{Cu}(\mathrm{II})$, and $\mathrm{Zn}$ (II) ions are synthesized and structurally characterized by $1 \mathrm{H}$ NMR, FTIR, and UV-Visible spectral techniques. The cytotoxic activity of the complexes and the uncoordinated ligand against human breast cancer (MCF-7) and chronic myelogenous leukemia cell line (human erythroleukemia) (K-562) cell lines exhibits good viability in the range of $50.16-55.16 \%$ at a concentration of $>100-110 \mu \mathrm{g} / \mathrm{mL}$ as compared to the inhibition in the untreated cells. Further, the metal complexes and ligand were screened against antibacterial strains of S. typhi, S. aureus, and E. coli. Both the cytotoxicity and antioxidant studies are correlated with computational docking analysis and powder XRD studies reviles that all complexes are in crystalline nature.
\end{abstract}

Keywords: Azo dye, solvent-free, $\mathrm{Fe}\left(\mathrm{HSO}_{4}\right)_{3}$, powder X-ray diffraction.

Submitted: April 26, 2017. Accepted: June 12, 2017.

Cite this: Shafeeulla R M, Krishnamurthy G, Bhojynaik H, Manjuraj T. Synthesis, Cytotoxicity, and Molecular Docking Study of Complexes Containing Thiazole Moiety. JOTCSA.

2017;4(3):787-810.

DOI: $10.18596 /$ jotcsa. 309261.

*Corresponding author. E-mail: gkmnaiksahyadri@gmail.com.Tel +91-9448774649. 


\section{INTRODUCTION}

Diazo coupling reactions is one of the most important class of organic reactions which is currently performed with liquid acid catalysts, such as $\mathrm{H}_{2} \mathrm{SO}_{4}, \mathrm{HF}, \mathrm{HBr}, \mathrm{HCl}, \mathrm{CF}_{3} \mathrm{COOH}$, and complexes of $\mathrm{BF}_{3}$ are frequently used in organic synthesis (1-3). This traditional approaches are inherently associated with environmental issues like pollution, catalyst waste, and issue in separation and recuperation (4). To overcome these issues an economical catalyst is employed (5). Current days the azo dyes grab much attention from synthetic organic chemists, due to its numerous groups of dyes consumed today like FMCG products such are textile, paper, coloring agents for foods and cosmetics industries. Other applications include emerging technologies like liquid crystals, organic photoconductors and non-linear optics (6-8). Azo dyes have got much attentions from different branches of chemistry and they show more prominent applications like colorants in the textile and digital printing, photography industries (9-11) liquid crystals (12) chiral switches in photochemistry (13) and for molecular recognition (14). Azo dyes exhibit important pharmacological activities like anti-inflammatory (15), plant growth regulating properties (16). Antipyretic $(17)$ and antitumor $(18,19)$ are also reported. The metal complexes derived from azo dyes have been investigated by many workers (20-23) and their complexes have been extensively used in many industries like dyes, synthetic leather and vinyl polymers. The applications of metal complexes of dyes not limited for industries but also in the field of pharmacology such as inhibition of DNA, RNA, and protein synthesis, nitrogen fixation, and carcinogenesis $(24,25)$. 5-Methyl-2-phenyl-2,4-dihydro-3H-pyrazol-3-one is the biological potent organic moiety $(26,27)$. Many researchers work on metal chelate of 5-methyl-2-phenyl2,4-dihydro-3H-pyrazol-3-one (28-32) but the catalytic synthesis of dyes from this organic moiety is not reported.

The aim of the present study was to synthesize the 5-methyl-2-phenyl-4-[(E)-1,3-thiazol-2-yldiazenyl]-2,4-dihydro-3H-pyrazol-3-one (Dy) via the diazotization reaction of 5-methyl-2phenyl-2,4-dihydro-3H-pyrazol-3-one with 2-aminothaizole using the iron(III) hydrogen sulfate, $\mathrm{Fe}\left(\mathrm{HSO}_{4}\right)_{3}$, as an economical catalyst and their metal chelates, screening for in-silico molecular docking studies followed by antimicrobial and cytotoxic activities.

\section{EXPERIMENTAL}

\section{Materials and methods}

All the chemicals used in this study were pure and AR grade. 2-Aminothiazole, ethanol, DMSO, were procured from Sigma-Aldrich and all the metal salts were obtained from Hi-Media and the solvents were used after purification by distillation (33). The human breast cancer (MCF-7) cell line was obtained from National center for cell science (NCCS), Pune, India. FTIR spectra were recorded as $\mathrm{KBr}$ pellets in the Bruker Alpha FT-IR Spectrometer, $1 \mathrm{H}$ NMR were recorded on a Bruker DPX 400, $\delta$ values relative to the deuterated DMSO. Magnetic susceptibilities were 
measured at room temperature by the Gouy method. The molar conductance measurements were measured in solution of the metal complexes in DMF $\left(10^{-3} \mathrm{M}\right)$ using Equip-tronics EQ-660A conductivity meter, Mass spectra are recorded in a Quattro LC, Micro Mass spectrometer. Elemental analysis is obtained from a Vario-Micro Qub elemental analyzer. Absorbance is measured using Systronics UV-VIS spectrophotometer-119, X-ray diffractometer (PHILIPS PW3710) using CuKa $\left(1.5418 \mathrm{~A}^{\circ}\right.$ ) radiation operated at $45 \mathrm{kV}$ and $25 \mathrm{~mA}$ is used in $\mathrm{X}$-ray investigations.

\section{Synthesis of 5-methyl-2-phenyl-4-[(E)-1,3-thiazol-2-yldiazenyl]-2,4-dihydro-3H- pyrazol-3-one (Dy)}

To a stirred mixture of $\mathrm{NaNO}_{2}(2 \mathrm{mmol}, 0.28 \mathrm{~g}$ ) and silica gel $(1 \mathrm{~g})$, a suspension of an appropriate 2-aminothiazole ( $2 \mathrm{mmol})$ and ferric hydrogen sulfate (FHS) $(10 \mathrm{~mol} \%, 0.06 \mathrm{~g})$ in water (12 mL) was added. After the mixture was stirred for about 20-30 min, the solution of 5methyl-2-phenyl-2,4-dihydro-3H-pyrazol-3-one ( $2 \mathrm{mmol}, 0.6 \mathrm{~g}$ ) was added. The progress of the reaction was monitored by TLC using chloroform: methanol as eluent (9:1). After the completion of the reaction, the mixture was filtered and the residue was washed several times with hot water and product is recrystallized in ethanol. The synthetic route is represented in Scheme 1.

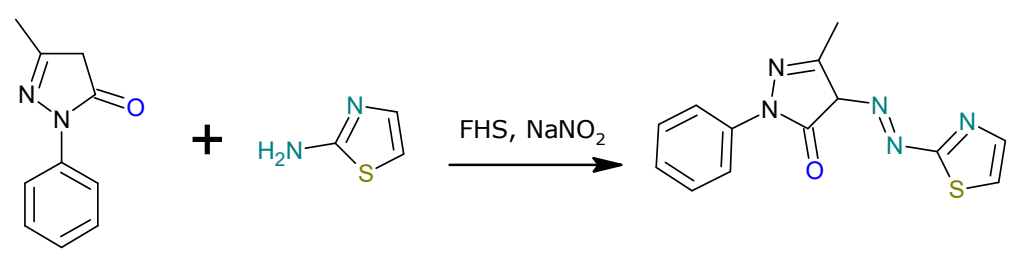

Scheme 1: Synthesis of 5-methyl-2-phenyl-4-[(E)-1,3-thiazol-2-yl-diazenyl]-2,4-dihydro-3Hpyrazol-3-one (Dy).

5-Methyl-2-phenyl-4-[(E)-1,3-thiazol-2-yldiazenyl]-2,4-dihydro-3H-pyrazol-3-one (Dy): Brick red, Yield :89\%, m.p. $148-150{ }^{\circ} \mathrm{C}$. (Anal.: C, 54.7; H, 3.7; N, 24.5;0, 5.6; S, 11.2; $\mathrm{C}_{13} \mathrm{H}_{11} \mathrm{~N}_{5} \mathrm{OS}$ calc.: C, 55.6; $\mathrm{H}, 3.8 ; \mathrm{N}, 23.4 ; \%$.). FT-IR (ATR, $\left.\mathrm{cm}^{-1}\right): \mathrm{u}(\mathrm{C}=\mathrm{O}) 1668, \mathrm{v}(\mathrm{C}=\mathrm{N}) 1594, \mathrm{v}(\mathrm{N}=\mathrm{N})$ 1505, v(C-S) 759. ${ }^{1} \mathrm{H}-\mathrm{NMR}\left(400 \mathrm{MHz}, \mathrm{CDCl}_{3}, \mathrm{ppm}\right): 7.91-7.20(\mathrm{~m}, 7 \mathrm{H}, \mathrm{Ar}-\mathrm{H}),. 2.84\left(\mathrm{~s}, 3 \mathrm{H}, \mathrm{CH}_{3}\right)$.

\section{Synthesis of metal complexes 1-4.}

A methanolic solution of metal chlorides $(0.461 \mathrm{~g}, 1.5 \mathrm{mmol})$ in $20 \mathrm{~mL}$ was added drop wise to a methanolic solution $(20 \mathrm{~mL})$ of the ligand $(1.044 \mathrm{~g}, 3 \mathrm{mmol})$ with continuous stirring (Scheme 2). The resulting solution was refluxed for 4-6 $\mathrm{h}$ and the solution was reduced to half of its initial volume. It was then allowed to stand overnight in a refrigerator. A colored complex was precipitated, which was separated by filtration under vacuum. It was washed thoroughly with distilled water and cold methanol and dried in vacuo over fused $\mathrm{CaCl}_{2}$ and was recrystallized from methanol $(35,36)$. 

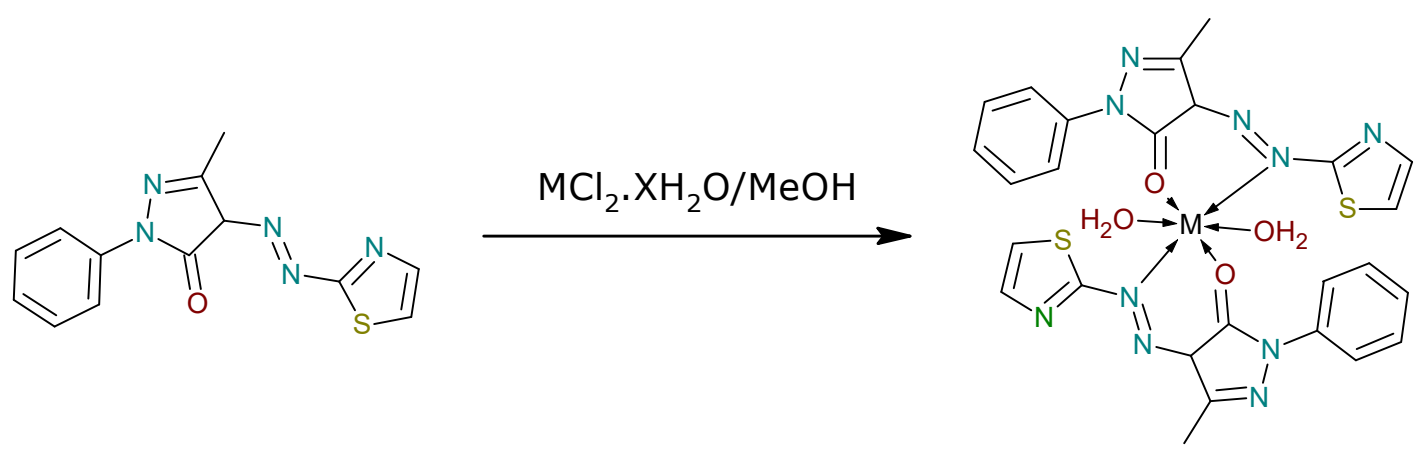

Scheme 2: Synthesis of metal complexes $(M=C u, C o, N i, Z n)$.

Result for 1: Light brown; yield $68 \%$; $\mathrm{mp},>300{ }^{\circ} \mathrm{C}$; $\mathrm{mw}, 670.2 \mathrm{~g} / \mathrm{mol}$; found for $\mathrm{C}_{26} \mathrm{H}_{24} \mathrm{CuN}_{10} \mathrm{O}_{4} \mathrm{~S}_{2}: \mathrm{C}: 46.72 ; \mathrm{H}: 3.62 ; \mathrm{N}: 20.96$, Calc. for C: 45.17; H: 3.28; N: 20.22. UV-Vis $(D M F): \lambda_{\max }(\log \varepsilon)=20,000 . F T-I R\left(\mathrm{~cm}^{-1}\right): v(C=O) 1603, v(C=N) 1586, v(N=N) 1581, v(C-S)$ 755, $v(M-O) 509, v(M-N) 477 . \wedge M=130 \Omega^{-1} \cdot \mathrm{cm}^{2} \mathrm{~mol}^{-1}$

Result for 2: Black brown; yield $63 \%$; $\mathrm{mp},>300^{\circ} \mathrm{C}$; $\mathrm{mw}, 665.6 \mathrm{~g} / \mathrm{mol}$; found for $\mathrm{C}_{26} \mathrm{H}_{24} \mathrm{CoN}_{10} \mathrm{O}_{4} \mathrm{~S}_{2}: \mathrm{C}: 47.16 ; \mathrm{H}: 3.65 ; \mathrm{N}: 21.10$, Calc. for C: 47.30; H: 3.44; N: 20.96. UV-Vis (DMF): $\lambda_{\max }(\log \varepsilon)=14,705,16,395 . F T-I R\left(\mathrm{~cm}^{-1}\right): v(C=O) 1630, v(C=N) 1583, v(N=N) 1492$, $\checkmark(C-S) 762, v(M-O) 511, v(M-N) 473 . \wedge M=128 \Omega^{-1} \cdot \mathrm{cm}^{2} \cdot \mathrm{mol}^{-1}$.

Result for 3: Dark brown; yield $62 \%$; mp, $>300^{\circ} \mathrm{C} ; \mathrm{mw}, 665.3 \mathrm{~g} / \mathrm{mol}$; found for $\mathrm{C}_{26} \mathrm{H}_{24} \mathrm{NiN}_{10} \mathrm{O}_{4} \mathrm{~S}_{2}$ : C: $47.09 ; \mathrm{H}: 3.70 ; \mathrm{N}: 21.72$, Calc. for C: $47.08 ; \mathrm{H}: 3.84 ; \mathrm{N}: 21.36$. UV-Vis (DMF): $\lambda_{\max }(\log \varepsilon)$ $=15,000,20,000,25,00$. FT-IR $\left(\mathrm{cm}^{-1}\right): \mathrm{V}(\mathrm{C}=\mathrm{O})$ 1606, $\mathrm{v}(\mathrm{C}=\mathrm{N})$ 1586, $\mathrm{v}(\mathrm{N}=\mathrm{N})$ 1477, $\mathrm{v}(\mathrm{C}-\mathrm{S})$ 757, $\checkmark(M-O) 510, v(M-N) 477 . \Lambda M=132 \Omega-1 . \mathrm{cm}^{2} \cdot \mathrm{mol}^{-1}$

Result for 4: Pale brown; yield 59\%; mp, $>300^{\circ} \mathrm{C} ; \mathrm{mw}, 672.0 \mathrm{~g} / \mathrm{mol}$; found for $\mathrm{C}_{26} \mathrm{H}_{24} \mathrm{~N}_{10} \mathrm{O}_{4} \mathrm{~S}_{2} \mathrm{Zn}$ : C: $46.60 ; \mathrm{H}: 3.65 ; \mathrm{N}: 20.90$, Calc. for C: 46.89; H: 3.46; N: 20.28. FT-IR $\left(\mathrm{cm}^{-1}\right): \mathrm{V}(\mathrm{C}=\mathrm{O})$ 1607, $v(C=N) 1582, v(N=N) 1485, v(C-S) 757, v(M-O) 509, v(M-N) 474 . \Lambda M=125 \Omega^{-1} \cdot \mathrm{cm}^{2} \cdot \mathrm{mol}^{-1}$.

\section{Molecular docking studies}

Molecular docking for the synthesized compounds is done by as per our previous work $(37,38)$. For antioxidant and cytotoxic molecular docking study we use (PDB code: 3MNG) as antioxidant enzyme receptor and (PDB code: 2A91) as EGFR kinase domain was used throughout the work. Followed by butylated hydroxytoluene (BHT) and Actinoin as standards for docking studies. The docking results of both antioxidant and cytotoxic guided for wet analysis.

\section{Antimicrobial activity}

The antibacterial activity was determined using the agar disc diffusion method against four Gram-negative and Gram-positive bacterial strains. The nutrient agar $(18 \mathrm{~g} / \mathrm{L})$ medium at $4{ }^{\circ} \mathrm{C}$ were maintained for microorganisms. The agar media was prepared by suspending $2 \mathrm{~g}$ nutrient 
Shafeeulla R, Krishnamurthy, Bhojynaik, Manjuraj, JOTCSA. 2017; 4(3): 787-810. RESEARCH ARTICLE agar in $100 \mathrm{~mL}$ of distilled water. The $\mathrm{pH}$ maintained to neutral value and finally autoclaved, after some interval of time to bring down the media temperature to $45^{\circ} \mathrm{C}$. The test compounds were dissolved in DMF and $5 \mu \mathrm{L}$ of each compound with final concentrations of $10.0 \mu \mathrm{g} / \mathrm{disc}$, $25.0 \mu \mathrm{g} /$ disc and $50 \mu \mathrm{g} /$ disc was poured on 4-mm sterile paper discs and placed on nutrient agar plates. In each plate DMF served as negative control and the standard antibacterial drug cefexime $(1 \mathrm{mg} / \mathrm{mL})$ served as positive control.

Three plates of each bacterial strain were prepared and incubated at $37^{\circ} \mathrm{C}$ for $24 \mathrm{~h}$. The antibacterial activity was determined by measuring the zones of inhibition $(\mathrm{mm})$. The same procedure was followed for the antifungal assay against $A$. niger, A. flavus, A. fumigates, and potato dextrose agar (PDA) was the media (39). Fungal spores were spread on the surface of each agar plate instead of the bacterial culture and the plates were incubated at $28^{\circ} \mathrm{C}$ for $24 \mathrm{~h}$. In each plate DMF served as negative control and Fluconazole $(1 \mathrm{mg} / \mathrm{mL})$ was used as positive control. The experiments were carried out in triplicate. The lowest concentration at which inhibition was shown was considered as minimum inhibitory concentration (MIC) $(40,41)$.

\section{Antioxidant activity}

\section{DPPH radical scavenging method}

Free radical-scavenging capacities of the ligand (Dy) and their metal complexes were determined using the stable 2,2-diphenyl-1-picrylhydrazyl radical (DPPH). An aliquot of 25-75 mg concentrations of synthesized compounds in methanol was added to $3 \mathrm{~mL}$ of $0.004 \% \mathrm{w} / \mathrm{v} \mathrm{DPPH}$ radical solution and each test tube was made up to final volume of $4 \mathrm{~mL}$. butylated hydroxytoluene (BHT) was used as a standard and dissolved in methanol to get the same concentration as that of synthesized compounds. Each mixture was vortexed for a few seconds and allowed to stand in the dark for 10 minute at ambient temperature. The absorbance of each reaction mixture was measured at $517 \mathrm{~nm}$ against a blank.

Nitric oxide (NO) scavenging method

All the tested samples in various concentrations $(25,50$ and $75 \mu \mathrm{g} / \mathrm{mL}$ ) were prepared in DMF and made homogeneous. $0.75 \mathrm{~mL}$ of phosphate buffer saline $(0.2 \mathrm{M}, \mathrm{pH} 7.4)$ and $0.5 \mathrm{~mL}$ of sodium nitroprusside $(10 \mathrm{mM})$ were mixed together to generate nitric oxide radicals (NO) and this solution were added to the test compounds and incubated for $120 \mathrm{~min}$ at $25^{\circ} \mathrm{C}$. The reaction mixture of the above samples ( $1 \mathrm{~mL}$ each) was treated with $1 \mathrm{~mL}$ of Griess reagent ( $1 \%$ sulfanylamide, $2 \% \quad \mathrm{H}_{3} \mathrm{PO}_{4}$ and $0.1 \%$ naphthylene diamine dihydrochloride). Butylated hydroxytoluene (BHT) was used as a positive control. The absorbance was measured at $546 \mathrm{~nm}$. The ability to scavenge from both radicals was calculated as follows:

$$
\text { Scavenging ratio }(\%)=\left[\left(A_{i}-A_{0}\right) /\left(A_{c}-A_{o}\right)\right] \times 100 \%
$$


Shafeeulla R, Krishnamurthy, Bhojynaik, Manjuraj, JOTCSA. 2017; 4(3): 787-810. RESEARCH ARTICLE blank in the absence of the test compound, $A_{c}$ is the absorbance in the absence of the test solution.

\section{In-vitro anticancer activity - Cell culture}

The human cancer cells (K-562 ATCC $®$ CCL-243 ${ }^{\mathrm{TM}}$ ) and (MCF7-ATCC $®$ HTB 22 $2^{\mathrm{TM}}$ ) were maintained in Modified Eagles Medium (MEM) supplemented with 10\% FCS, 2\% essential amino acids, $1 \%$ each of glutamine, non-essential amino acids, vitamins and $100 \mathrm{U} / \mathrm{mL}$ PenicillinStreptomycin. Cells were sub-cultured at $80-90 \%$ confluence and incubated at $37{ }^{\circ} \mathrm{C}$ in a humidified incubator supplied with $5 \% \mathrm{CO}$. The stock cells were maintained in $75 \mathrm{~cm}^{2}$ tissue culture flask.

\section{Cell viability assay}

The cytotoxicity effect of test samples was performed by 5 -diphenyl-2H-tetrazolium bromide (MTT) assay. Briefly, cultured cells $\left(1 \times 10^{-6}\right.$ cells $\left./ \mathrm{mL}\right)$ were placed in 96 flat-bottom well plates, then the cells were exposed to different concentrations of prepared samples $(1-100 \mu \mathrm{g} / \mathrm{mL})$ and incubated at $37{ }^{\circ} \mathrm{C}$ for about $24 \mathrm{~h}$ in $5 \% \mathrm{CO}_{2}$ atmosphere. After $24 \mathrm{~h}$ incubation, $\mathrm{MTT}(10 \mu \mathrm{L})$ was added to the incubated cancer cells and further incubated at $37^{\circ} \mathrm{C}$ for about $4 \mathrm{~h}$ in same environment. Thereafter, we dissolved $200 \mu \mathrm{L}$ of formazan crystals in DMSO and monitored the absorbance at $578 \mathrm{~nm}$ with reference filter as $630 \mathrm{~nm}$. The cytotoxicity effect was calculated as:

$$
\begin{gathered}
\text { Cytotoxicity }(\%)=1-\left(\frac{\text { mean absorbance of }}{\text { mean absorbance of - ve }}\right) \times 100 \\
\text { Cell viability }(\%)=100-\text { Cytotoxicity }(\%)
\end{gathered}
$$

\section{RESULTS AND DISCUSSION}

\section{Mass spectrum}

The mass spectrum of the ligand (Figure 1) obtained by using of Quattro LC, Micro mass spectrometer (ESI) showed the molecular ion peak at $\mathrm{m} / \mathrm{z} 285.0$ which coincide with the formula weight within the precision limit of \pm 0.02 . Metastable ion(s) were not observed, thus representing the proposed fragmentation pattern of the ligand (Scheme 3 ).

\section{${ }^{1}$ H NMR spectrum}

The ${ }^{1} \mathrm{H}$ NMR spectrum (Figure 2) of the ligand in DMSO-d show a doublet at 7.91 and $7.88 \mathrm{ppm}$ shifts is for $\mathrm{H} 1$ and $\mathrm{H} 2$ protons respectively. The doublet at 7.59-7.58 ppm is assigned to the $\mathrm{H} 6$ proton. The other two protons $\mathrm{H} 5$ and $\mathrm{H} 7$ resonated together but was slightly distorted by coupling effect from $\mathrm{H} 6$ and $\mathrm{H} 8$ which appeared as a multiplet peak at $7.47 \mathrm{ppm}$ and a doublet peak showed at $7.34 \mathrm{ppm}$ assigned for $\mathrm{H} 4$ and $\mathrm{H} 8$ protons, at the extreme right of the spectrum a singlet signal appeared at $2.84 \mathrm{ppm}$ is assigned for methyl group H3 proton. However, the chemical shifts and multiplicity patterns are in agreement with the structure of the compound (Figure 3). 
<smiles>CC1=NN(c2ccccc2)C(=O)C1/N=N/c1nccs1</smiles>

Figure 3: The structure of the ligand for H NMR.

\section{FTIR spectroscopy}

A comparative FTIR spectral study of the ligand and its metal complexes has been recorded as $\mathrm{KBr}$ pellets. Some significant IR bands for the uncoordinated ligand and their metal complexes have been listed in Table 1. The free ligand showed both a strong band and a weak band at 1668 $\mathrm{cm}^{-1}$ and $3090 \mathrm{~cm}^{-1}$ which were attributed to $\mathrm{v}(\mathrm{CO})$ and $\mathrm{v}(\mathrm{C}-\mathrm{H})$ aromatic (42). The IR spectrum of the ligand displays bands at $1594 \mathrm{~cm}^{-1}$ which may be assigned to the $v(C=N)$ thiazole ring and the strong band belongs to $v(N=N)$ was found at $1501 \mathrm{~cm}^{-1}(43)$. The hypsochromic shift was observed for the $v(\mathrm{CO})$ band at $1668 \mathrm{~cm}^{-1}$ assigned in the spectrum of the ligand. This carbonyl band showed reduction in intensities between 1668 and $1603 \mathrm{~cm}^{-1}$ region observed due to the coordination to central metal ions (44). However, the $v(N=N)$ band at $1501 \mathrm{~cm}^{-1}$ in the free ligand appeared to have shifted to lower frequencies in the spectrum of the metal complexes due to donation of the lone pair of electron present on the nitrogen atom to the metal ions in the complex. After complexation, the peaks appeared almost in the same region between 1594$1586 \mathrm{~cm}^{-1}$ and $759-757 \mathrm{~cm}^{-1}$ shows that the electrons from the nitrogen and sulfur of the thiazole ring are not donated for bonding with metal ion $(45,46)$. All the complexes show broad bands in the region 3434- $3439 \mathrm{~cm}^{-1}$ which may be assigned to $\mathrm{v}(\mathrm{O}-\mathrm{H})$ of coordinated water (47). This suggests that the nitrogen and sulfur atom of the thiazole ring are not participated in the coordination. This was further supported from existence of new metal- ligand band in the complex spectrum ranging from $509-511 \mathrm{~cm}^{-1}$ for $\mathrm{M}-\mathrm{O}$ band and $474-477 \mathrm{~cm}^{-1}$ for $\mathrm{M}-\mathrm{N}$ band and the elemental analysis as shown in Table 2. 
Shafeeulla R, Krishnamurthy, Bhojynaik, Manjuraj, JOTCSA. 2017; 4(3): 787-810. RESEARCH ARTICLE

Table 1: IR spectral data $\left(\mathrm{cm}^{-1}\right)$ of Ligand $(\mathrm{L})$ and metal complexes.

\begin{tabular}{lllllll}
\hline Ligand/complex & $\mathbf{v}(\mathbf{C}=\mathbf{O})$ & $\mathbf{v}(\mathbf{C}=\mathbf{N})$ & $\mathbf{v}(\mathbf{N}=\mathbf{N})$ & $\mathbf{v}(\mathbf{C}-\mathbf{S})$ & $\mathbf{v}(\mathbf{M - O})$ & $\mathbf{v ( M - N )}$ \\
\hline Ligand $(\mathrm{L})$ & 1668 & 1594 & 1501 & 759 & - & - \\
{$\left[\mathrm{CuL} 2 \mathrm{H}_{2} \mathrm{O}\right] \mathrm{Cl}_{2}(\mathbf{1})$} & 1603 & 1586 & 1481 & 757 & 509 & 477 \\
{$\left[\mathrm{CoL} 2 \mathrm{H}_{2} \mathrm{O}\right] \mathrm{Cl}_{2}(\mathbf{2})$} & 1630 & 1583 & 1492 & 762 & 511 & 473 \\
{$\left[\mathrm{NiL} 2 \mathrm{H}_{2} \mathrm{O}\right] \mathrm{Cl}_{2}(\mathbf{3})$} & 1606 & 1586 & 1477 & 757 & 510 & 477 \\
{$\left[\mathrm{ZnL} 2 \mathrm{H}_{2} \mathrm{O}\right] \mathrm{Cl}_{2}(\mathbf{4})$} & 1607 & 1582 & 1485 & 757 & 509 & 474 \\
\hline
\end{tabular}

Table 2: Elemental analyses, colors, melting points and yield of Ligand and metal complexes.

\begin{tabular}{|c|c|c|c|c|c|c|c|c|}
\hline \multirow[t]{2}{*}{ Ligand/Complex } & \multirow[t]{2}{*}{ Color } & \multirow[t]{2}{*}{ Melting point $\left({ }^{\circ} \mathrm{C}\right)$} & \multicolumn{4}{|c|}{ Found (Calc.) \% } & \multirow[t]{2}{*}{ Yield (\%) } & \multirow[t]{2}{*}{$\Lambda \mathrm{M} \mathrm{S} \mathrm{cm}{ }^{2} \mathrm{~mol}^{-1}$} \\
\hline & & & C & $\mathbf{H}$ & $\mathbf{N}$ & $\mathbf{M}$ & & \\
\hline Ligand (Dy) & Brick red & $148-150$ & $\begin{array}{l}54.72 \\
(55.65)\end{array}$ & $\begin{array}{l}3.76 \\
(3.86)\end{array}$ & $\begin{array}{l}24.55 \\
(23.46)\end{array}$ & - & 89 & - \\
\hline 1 & Light brown & $>300$ & $\begin{array}{l}46.72 \\
(45.17)\end{array}$ & $\begin{array}{l}3.62 \\
(3.28)\end{array}$ & $\begin{array}{l}20.96 \\
(20.22)\end{array}$ & $\begin{array}{l}9.86 \\
(9.62)\end{array}$ & 68 & 130 \\
\hline 2 & Black brown & $>300$ & $\begin{array}{l}47.16 \\
(47.30)\end{array}$ & $\begin{array}{l}3.65 \\
(3.44)\end{array}$ & $\begin{array}{l}21.10 \\
(20.96)\end{array}$ & $\begin{array}{l}9.70 \\
(9.89)\end{array}$ & 63 & 128 \\
\hline 3 & Dark brown & $>300$ & $\begin{array}{l}47.09 \\
(47.48)\end{array}$ & $\begin{array}{l}3.70 \\
(3.84)\end{array}$ & $\begin{array}{l}21.72 \\
(21.36)\end{array}$ & $\begin{array}{l}9.67 \\
(9.30)\end{array}$ & 62 & 132 \\
\hline 4 & Pale brown & $>300$ & $\begin{array}{l}46.60 \\
(46.89)\end{array}$ & $\begin{array}{l}3.65 \\
(3.46)\end{array}$ & $\begin{array}{l}20.90 \\
(20.28)\end{array}$ & $\begin{array}{l}9.76 \\
(9.48)\end{array}$ & 59 & 125 \\
\hline
\end{tabular}




\section{Electronic spectra and magnetic moment measurements}

The UV-Vis spectrum of the ligand and their metal complexes are recorded in DMF and the values are reported in Table 3 . The free ligand showed two recognizable absorption bands at 36,101 and $26,315 \mathrm{~cm}^{-1}$ would be due to the $n-\Pi^{*}$ and $n-n^{*}$ transitions, respectively. The spectrum of the $\mathrm{Cu}$ (II) complex 1 showed a absorption band at $20,000 \mathrm{~cm}^{-1}$ which is attributed to the transition ${ }^{2} \mathrm{E}_{g} \rightarrow{ }^{2} \mathrm{~T}_{\mathrm{g}}$ due to distorted octahedral geometry $(48,49)$. Further confirmation was done by magnetic moment values 1.78 B.M. which is consistent with proposed distorted octahedral geometry for $\mathrm{Cu}(\mathrm{II})$ complex. The $\mathrm{Co}$ (II) complex 2 showed absorption band at $14,705 \mathrm{~cm}^{-1}$ and $16,393 \mathrm{~cm}^{-1}$ due to the transitions ${ }^{4} \mathrm{~T}_{1 \mathrm{~g}}(\mathrm{~F}) \rightarrow{ }^{4} \mathrm{~A}_{2 \mathrm{~g}}(\mathrm{~F})$ and ${ }^{4} \mathrm{~T}_{1 \mathrm{~g}}(\mathrm{~F}) \rightarrow{ }^{4} \mathrm{~A}_{2 \mathrm{~g}}(\mathrm{P})\left(\mathrm{V}_{2}\right)$, respectively, the $\mathrm{Co}$ (II) complex also showed magnetic moment at 4.56 B.M. These results suggested the presence of octahedral geometry for $\mathrm{Co}$ (II) complex. $(50,51)$. The $\mathrm{Ni}$ (II) complex 3 showed three bands at $25,000 \mathrm{~cm}^{-1}, 20,000 \mathrm{~cm}^{-1}$ and $15,384 \mathrm{~cm}^{-1}$ which are assignable to ${ }^{3} A_{2 \mathrm{~g}}$ $(F) \rightarrow{ }^{3} T_{2 g}(F)\left(V_{1}\right),{ }^{3} A_{2 g}(F) \rightarrow{ }^{3} T_{1 g}(F)\left(V_{2}\right)$ and ${ }^{3} A_{2 g}(F) \rightarrow{ }^{3} T_{1 g}(P)\left(V_{3}\right)$ transitions respectively. The spectral data indicate that the $\mathrm{Ni}(\mathrm{II})$ ion coordinated through octahedral geometry. The magnetic moment of $\mathrm{Ni}$ (II) complex is 2.74 B.M. These results suggested the presence of octahedral geometry for $\mathrm{Ni}(\mathrm{II})$ complex $(52,53)$.

\section{Powder X-ray diffraction study of complexes}

Powder X-ray diffraction graph of the complexes were recorded over the $2 \theta=0-80^{\circ}$ range. The major peaks of relative intensity greater than $10 \%$ were indexed using a computer software. The diffraction data like angle (2h), interplanar spacing (d) and relative intensity (\%) have been summarized in (Table 4) from the data all 1-4 show sharp crystalline peaks indicating their crystalline nature. The XRD patterns of all complexes are very similar and suggest that the complexes have similar structure. The average crystallite sizes of the complexes dxrd were calculated using the Sherrers formula [54]. 1 2, 3 and 4 have a crystallite size of 28.25, 28.16, 15.04 and $42.06 \mathrm{~nm}$, respectively, suggesting that the complexes are in a nano-crystalline phase and the X-ray diffraction data of 1 are shown in Table 5 and spectrum in Figure 4. 
Shafeeulla R, Krishnamurthy, Bhojynaik, Manjuraj, JOTCSA. 2017; 4(3): 787-810. RESEARCH ARTICLE

Table 3: Electronic spectral data $\left(\mathrm{cm}^{-1}\right)$ and magnetic studies for Ligand and its metal complexes.

\begin{tabular}{|c|c|c|c|}
\hline Entry & Transitions $\left(\mathrm{cm}^{-1}\right)$ & Transitions & Meff (BM) \\
\hline Ligand (Dy) & $\begin{array}{l}36,101 \\
26,315\end{array}$ & $\begin{array}{l}\Pi-\Pi^{*} \\
\Pi-\Pi^{*}\end{array}$ & - \\
\hline 1 & 20 & ${ }^{2} \mathrm{E}_{g} \rightarrow{ }^{2} \mathrm{~T}_{2 g}$ & 1.78 \\
\hline 2 & $\begin{array}{l}16,395 \\
14,705\end{array}$ & $\begin{array}{l}{ }^{4} T_{1 g}(F) \rightarrow{ }^{4} A_{2 g}(P)\left(V_{2}\right) \\
{ }^{4} T_{1 g}(F) \rightarrow{ }^{4} A_{2 g}(F)\end{array}$ & 4.56 \\
\hline 3 & $\begin{array}{l}25,385 \\
20,000 \\
15,000\end{array}$ & $\begin{array}{l}{ }^{3} A_{2 g}(F) \rightarrow{ }^{3} T_{2 g}(F)\left(V_{1}\right) \\
{ }^{3} A_{2 g}(F) \rightarrow{ }^{3} T_{1 g}(F)\left(V_{2}\right) \\
{ }^{3} A_{2 g}(F) \rightarrow{ }^{3} T_{1 g}(P)\left(V_{3}\right)\end{array}$ & 2.74 \\
\hline 4 & Diamagnetic & & Diamagnetic \\
\hline
\end{tabular}

Table 4: PXRD spectral data of 1-4.

Complexes $2 \theta$ d Relative intensity Full width at half maximum

$\begin{array}{lllll}\mathbf{1} & 26.42 & 3.37 & 100 & 0.32 \\ \mathbf{2} & 21.32 & 4.16 & 100 & 0.20 \\ \mathbf{3} & 19.74 & 4.49 & 100 & 0.56 \\ \mathbf{4} & 18.61 & 4.76 & 100 & 0.20\end{array}$


Shafeeulla R, Krishnamurthy, Bhojynaik, Manjuraj, JOTCSA. 2017; 4(3): 787-810. RESEARCH ARTICLE

Table 5: X-ray diffraction data of 1.

\begin{tabular}{|c|c|c|c|c|c|c|c|c|}
\hline Peak no & $2 \theta$ & $\theta$ & $\operatorname{Sin} \theta$ & h k I & d & & Intensity & $a$ in $\AA$ \\
\hline & & & & & Cal & obs & & \\
\hline 1 & 12.382 & 6.19125 & 0.1078 & 152 & 7.14243 & 7.1464 & 339.6 & 3.62 \\
\hline 2 & 13.343 & 6.6719 & 0.1161 & 191 & 6.62998 & 6.6340 & 451.39 & 3.62 \\
\hline 4 & 14.424 & 7.21225 & 0.1255 & 206 & 6.13561 & 6.1355 & 267.93 & 3.62 \\
\hline 5 & 15.708 & 7.8543 & 0.1364 & 974 & 5.63681 & 5.6313 & 196.12 & 3.62 \\
\hline 6 & 17.150 & 8.57515 & 0.1491 & 969 & 5.16609 & 5.1655 & 336.55 & 3.62 \\
\hline 7 & 17.601 & 8.8005 & 0.1529 & 822 & 5.03479 & 5.0351 & 194.86 & 3.62 \\
\hline 8 & 18.619 & 9.3097 & 0.1617 & 133 & 4.76165 & 4.7634 & 195.50 & 3.62 \\
\hline 9 & 19.225 & 9.6128 & 0.1669 & 172 & 4.61285 & 4.6142 & 382.53 & 3.62 \\
\hline 10 & 21.789 & 10.8947 & 0.1890 & 121 & 4.07554 & 4.0754 & 211.51 & 3.62 \\
\hline 11 & 23.237 & 11.6189 & 0.2014 & 216 & 3.8247 & 3.8261 & 508.84 & 3.62 \\
\hline 12 & 25.309 & 12.6547 & 0.2190 & 210 & 3.51614 & 3.5161 & 442.26 & 3.62 \\
\hline 13 & 26.420 & 13.2102 & 0.2285 & 372 & 3.37075 & 3.3716 & 974.94 & 3.62 \\
\hline 14 & 29.318 & 14.65905 & 0.2530 & 104 & 3.04385 & 3.0448 & 125.80 & 3.62 \\
\hline 15 & 36.042 & 18.0214 & 0.3093 & 802 & 2.48987 & 2.4900 & 74.07 & 3.62 \\
\hline 16 & 44.889 & 22.4446 & 0.3817 & 568 & 2.01759 & 2.0177 & 28.34 & 3.62 \\
\hline
\end{tabular}




\section{Antimicrobial activity}

The ligand and its metal complexes were tested on their antimicrobial activity against bacterial (Salmonella typhi, Staphylococcus aureus, Escherichia coli) and fungal (Aspergillus niger, Aspergillus flavus, Aspergillus fumigatus) strains by the agar disc diffusion method and results are given in Table $6 \mathrm{a}$ and $6 \mathrm{~b}$. Cefixime and roxithromycin are standard drugs and were used as references. The highest inhibition activities were observed for $\mathbf{1}, \mathbf{2}$ and $\mathbf{3}$. While the ligand and 4 did not show significant activity comparable to that of the standard drugs Cefixime at concentrations of 50,25 and $10 \mu \mathrm{g} /$ disc which represent the sensitive nature of the compounds. However, these complexes also tested for the fungal strains, exhibited least activity compared to standard fluconazole except $\mathbf{2}$ and $\mathbf{3}$.

\section{Antioxidant studies: DPPH and Nitric oxide radical scavenging methods}

DPPH radical scavenging results of the synthesized ligand and metal complexes showed a moderate activity. The metal complexes exhibited more radical scavenging inhibition effects than that of the ligand. The $\mathbf{1}$ exhibited potent antioxidant effect nearly close the standard BHT and have potential to be applied as free radical scavengers and s free radical scavengers and $\mathbf{2}$ and 4 complexes showed condensed antioxidant activity and $\mathbf{3}$ and the ligand showed moderate activity. We found that the inhibitory effect of the compounds tested on NO is concentrationdependent and suppression ratio increases with increasing sample concentrations. The $\mathbf{1}$ is the most effective among all the complexes. The $\mathbf{2}, \mathbf{3}$, and the ligand showed better activity, while the 4 does not show any nitric oxide activity. Both methods of antioxidant activities are shown in Figure 5.

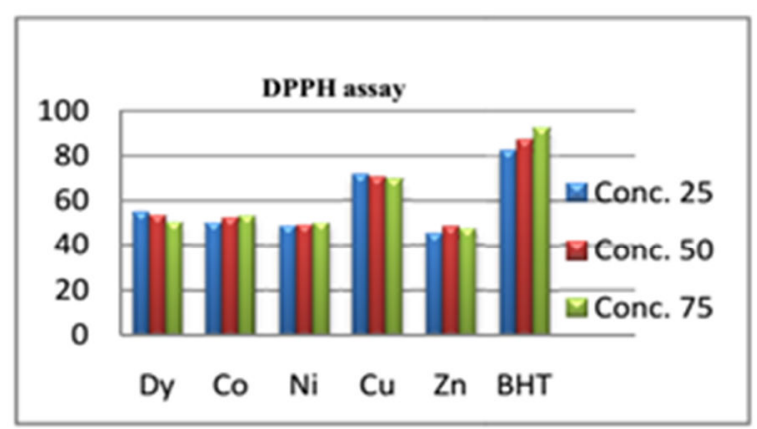

(a)

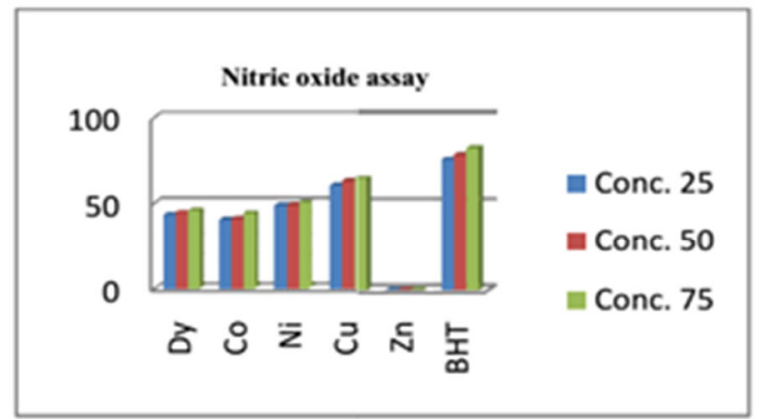

(b)

Figure 5: Antioxidant activity (a) DPPH method (b) Nitric oxide method. 
Shafeeulla R, Krishnamurthy, Bhojynaik, Manjuraj, JOTCSA. 2017; 4(3): 787-810. RESEARCH ARTICLE

Table 6a:- Antimicrobial activity of ligand and complexes.

\begin{tabular}{lllll}
\hline Compound Conc & \multicolumn{3}{c}{ Zone of inhibition (mm) } \\
& & S. typhi & S. aureus & E. coli \\
\hline Ligand & 25 & $12 \pm 0.3$ & $14 \pm 0.8$ & $11 \pm 0.2$ \\
& 10 & $10 \pm 0.4$ & $12 \pm 0.3$ & $09 \pm 0.4$ \\
& 50 & $22 \pm 0.7$ & $24 \pm 0.8$ & $23 \pm 0.8$ \\
$\mathbf{1}$ & 25 & $15 \pm 0.5$ & $20 \pm 0.3$ & $17 \pm 0.6$ \\
& 10 & $11 \pm 0.4$ & $17 \pm 0.7$ & $12 \pm 0.3$ \\
& 50 & $17 \pm 0.2$ & $19 \pm 0.4$ & $19 \pm 0.9$ \\
$\mathbf{2}$ & 25 & $16 \pm 0.5$ & $16 \pm 0.3$ & $15 \pm 0.4$ \\
& 10 & $10 \pm 0.3$ & $14 \pm 0.3$ & $11 \pm 0.3$ \\
$\mathbf{3}$ & 50 & $22 \pm 0.7$ & $24 \pm 0.8$ & $22 \pm 0.9$ \\
& 25 & $15 \pm 0.8$ & $18 \pm 0.7$ & $18 \pm 0.5$ \\
& 10 & $12 \pm 0.5$ & $15 \pm 0.7$ & $12 \pm 0.7$ \\
$\mathbf{4}$ & 50 & $15 \pm 0.7$ & $15 \pm 0.7$ & $15 \pm 0.3$ \\
& 25 & $12 \pm 0.8$ & $12 \pm 0.7$ & $13 \pm 0.7$ \\
& 10 & $09 \pm 0.3$ & $10 \pm 0.7$ & $11 \pm 0.7$ \\
& 50 & $25 \pm 0.01$ & $26 \pm 0.1$ & $24 \pm 0.1$ \\
Cefixime & 25 & $14 \pm 0.1$ & $23 \pm 0.3$ & $21 \pm 0.3$ \\
& 10 & $12 \pm 0.1$ & $19 \pm 0.4$ & $16 \pm 0.1$ \\
& 50 & $16 \pm 0.5$ & $20 \pm 0.4$ & $16 \pm 0.8$ \\
\hline
\end{tabular}

Table 6b: Antifungal activity of ligand and complexes.

\begin{tabular}{lllll}
\hline Compound & $\begin{array}{l}\text { Conc } \\
(\boldsymbol{\mu g} / \mathrm{disc})\end{array}$ & \multicolumn{3}{c}{ Zone of inhibition $(\mathbf{m m})$} \\
& & $\boldsymbol{A}$ niger & A flavus & $\boldsymbol{A}$ fumigatus \\
\hline Ligand & 50 & $14 \pm 06$ & $13 \pm 0.8$ & $11 \pm 0.1$ \\
& 25 & $12 \pm 0.2$ & $12 \pm 0.5$ & $10 \pm 0.3$ \\
$\mathbf{1}$ & 10 & $10 \pm 0.2$ & $09 \pm 0.4$ & $09 \pm 0.4$ \\
& 50 & $20 \pm 0.6$ & $18 \pm 0.7$ & $15 \pm 0.8$ \\
$\mathbf{2}$ & 25 & $15 \pm 0.2$ & $14 \pm 0.5$ & $10 \pm 0.1$ \\
& 10 & $11 \pm 0.4$ & $10 \pm 0.8$ & $10 \pm 0.5$ \\
$\mathbf{3}$ & 50 & $17 \pm 0.2$ & $16 \pm 0.7$ & $15 \pm 0.3$ \\
& 25 & $16 \pm 0.5$ & $14 \pm 0.5$ & $13 \pm 0.2$ \\
& 10 & $10 \pm 0.3$ & $10 \pm 0.2$ & $11 \pm 06$ \\
$\mathbf{4}$ & 50 & $15 \pm 0.8$ & $14 \pm 0.3$ & $16 \pm 0.1$ \\
& 25 & $12 \pm 0.5$ & $11 \pm 0.3$ & $12 \pm 0.6$ \\
& 10 & $09 \pm 0.3$ & $08 \pm 0.2$ & $09 \pm 0.6$ \\
& 50 & $16 \pm 0.4$ & $14 \pm 0.7$ & $12 \pm 0.7$ \\
Fluconazole & 50 & $24 \pm 0.01$ & $22 \pm 0.1$ & $23 \pm 0.1$ \\
& 25 & $13 \pm 0.8$ & $12 \pm 0.5$ & $11 \pm 0.5$ \\
& 10 & $10 \pm 0.7$ & $06 \pm 0.8$ & $07 \pm 0.8$ \\
& 10 & $10 \pm 0.1$ & $14 \pm 0.4$ & $10 \pm 0.1$ \\
\hline & & & &
\end{tabular}




\section{Molecular Docking study}

The result of the docking studies have been carried between the human antioxidant enzyme receptor (PDB:3MNG) and the complexes are reported in Table 5a. The complexes exhibited comparable binding interaction energy (E-total) values in the in the range of -212.25 to -327.01

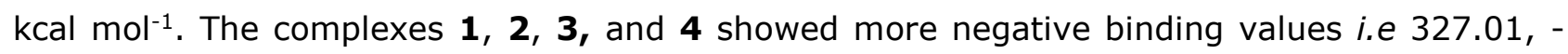
$280.78,-279.00$ and $-276.78 \mathrm{kcal} \mathrm{mol}^{-1}$ respectively when compared with the standard butylated hydroxytoluene (E-total value $-183.02 \mathrm{kcal} \mathrm{mol}^{-1}$ ). The stability of the complexes $\mathbf{1}$ and $\mathbf{2}$ was evaluated by determining the hydrogen bonding interactions was evaluated by determining the hydrogen bonding interactions was evaluated by determining the hydrogen bonding interactions between amino acids of the protein molecules with the complex between amino acids of the protein molecules with the complexes. The result indicate that the complex $\mathbf{1}$ having the highest E-total values $-337.07 \mathrm{kcal} \mathrm{mol}^{-1}$ has greater binding affinity and better hydrogen bond interactions with the human antioxidant enzyme active site residues.

The molecular docking results showed in Figure 6 represent that the $\mathbf{1}$ has ability to form two hydrogen bonds with amino acid CYS72 with hydrogen bond distances $3.011 \AA$ and $2.824 \AA$. Two more hydrogen bonds formed with amino acid PHE37 with bond distance of $2.751 \AA$ and 2.520 $\AA$. Single hydrogen bond can form between the $\mathbf{1}$ and the amino acids VAL39, LEU73 ALA71 and GLY38 of $2.945 \AA, 2.944 \AA, 2.660 \AA$, and $2.545 \AA$. The other interacting amino acids are CYS72, ALA71, GLY38, VAL70 and VAL35. The interaction of 2 represented in Figure 7 formed three hydrogen bonds with amino acids GLY38 with bond distances of $2.976 \AA$, $2.963 \AA$ and $2.795 \AA$. Single hydrogen bond formed between the $\mathbf{2}$ and the amino acid ARG95, PHE37, SER74, LEU73, VAL70, CYS72, VAL35 with bond distance $3.064 \AA, 3.057 \AA, 3.200 \AA, 2.967 \AA, 2.733 \AA, 2.638 \AA$ and $2.654 \AA$ The other interacting amino acids were CYS72, VAL35, HIS51, VAL35. 
Shafeeulla R, Krishnamurthy, Bhojynaik, Manjuraj, JOTCSA. 2017; 4(3): 787-810. RESEARCH ARTICLE

Table 5a- Antioxidant Docking scores.

\begin{tabular}{lll}
\hline Entry & \multicolumn{2}{c}{ Receptor PDB code $\begin{array}{l}\Delta \mathbf{G}(\mathbf{k c a l} / \mathbf{m o l}) \text { with } \\
\text { MurB }\end{array}$} \\
\hline Ligand & $3 \mathrm{MNG}$ & -212.25 \\
$\mathbf{1}$ & $3 \mathrm{MNG}$ & -327.01 \\
$\mathbf{2}$ & $3 \mathrm{MNG}$ & -280.78 \\
$\mathbf{3}$ & $3 \mathrm{MNG}$ & -279.00 \\
$\mathbf{4}$ & $3 \mathrm{MNG}$ & -273.78 \\
Butylated hydroxytoluene (STD) & $3 \mathrm{MNG}$ & -183.02 \\
\hline
\end{tabular}

Table 5b- Cytotoxic Docking Scores.

\begin{tabular}{lll}
\hline Entry & Receptor PDB code & $\begin{array}{l}\Delta \mathbf{G}(\mathbf{k c a l} / \mathrm{mol}) \text { with } \\
\text { MurB }\end{array}$ \\
\hline Ligand & $2 \mathrm{~A} 91$ & -217.95 \\
$\mathbf{1}$ & $2 \mathrm{~A} 91$ & -323.66 \\
$\mathbf{2}$ & $2 \mathrm{~A} 91$ & -316.42 \\
$\mathbf{3}$ & $2 \mathrm{~A} 91$ & -313.96 \\
$\mathbf{4}$ & $2 \mathrm{~A} 91$ & -306.96 \\
Actinoin (STD) & $2 \mathrm{~A} 91$ & -235.99 \\
\hline
\end{tabular}



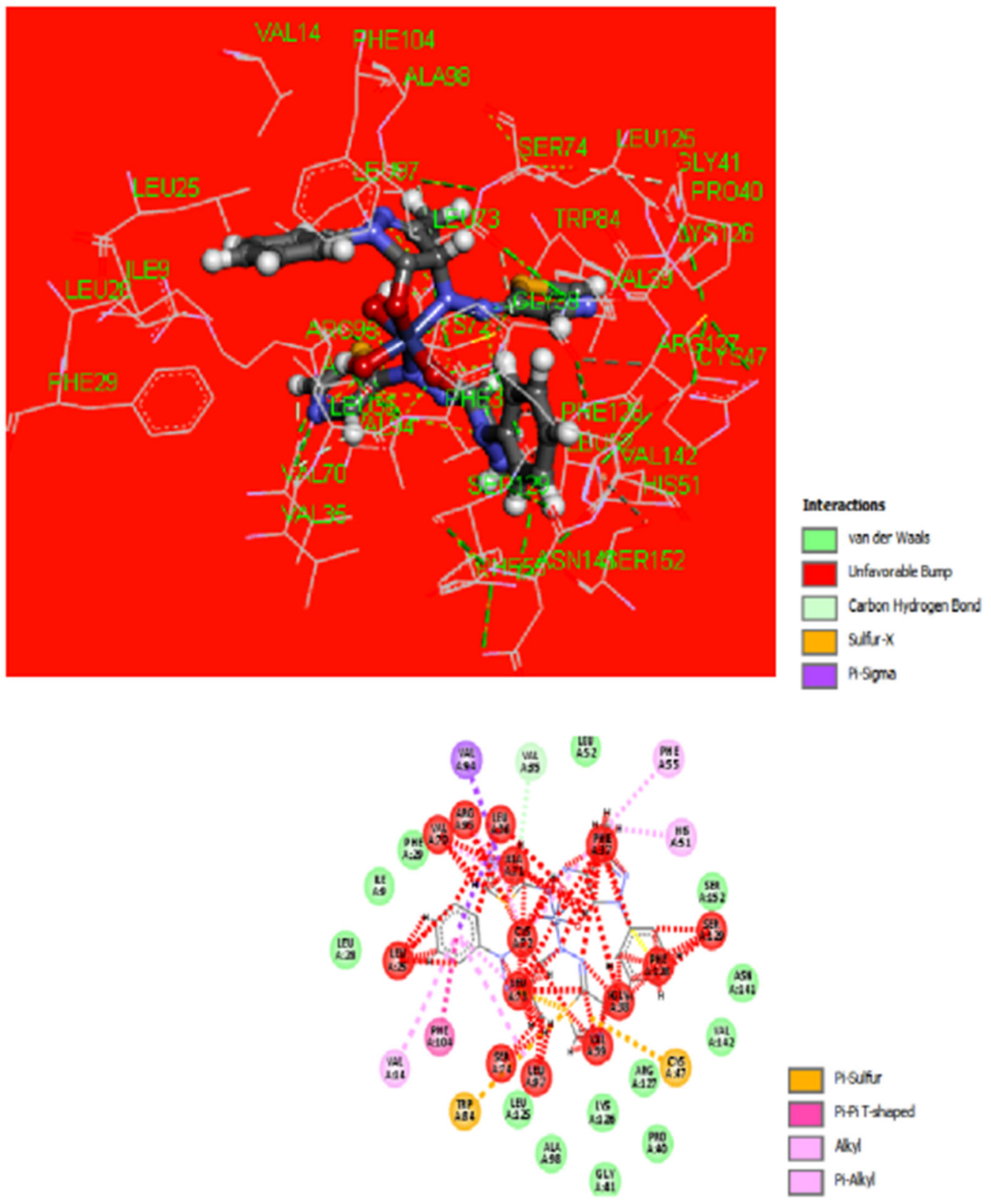

Figure 6: Interaction of 1 with amino acids of 3MNG (top) 3D-structure of complex (ball and stick model Oxygen-red, Nitrogen-blue) protein receptor (stick model) (bottom) 2D-structure of complex. 

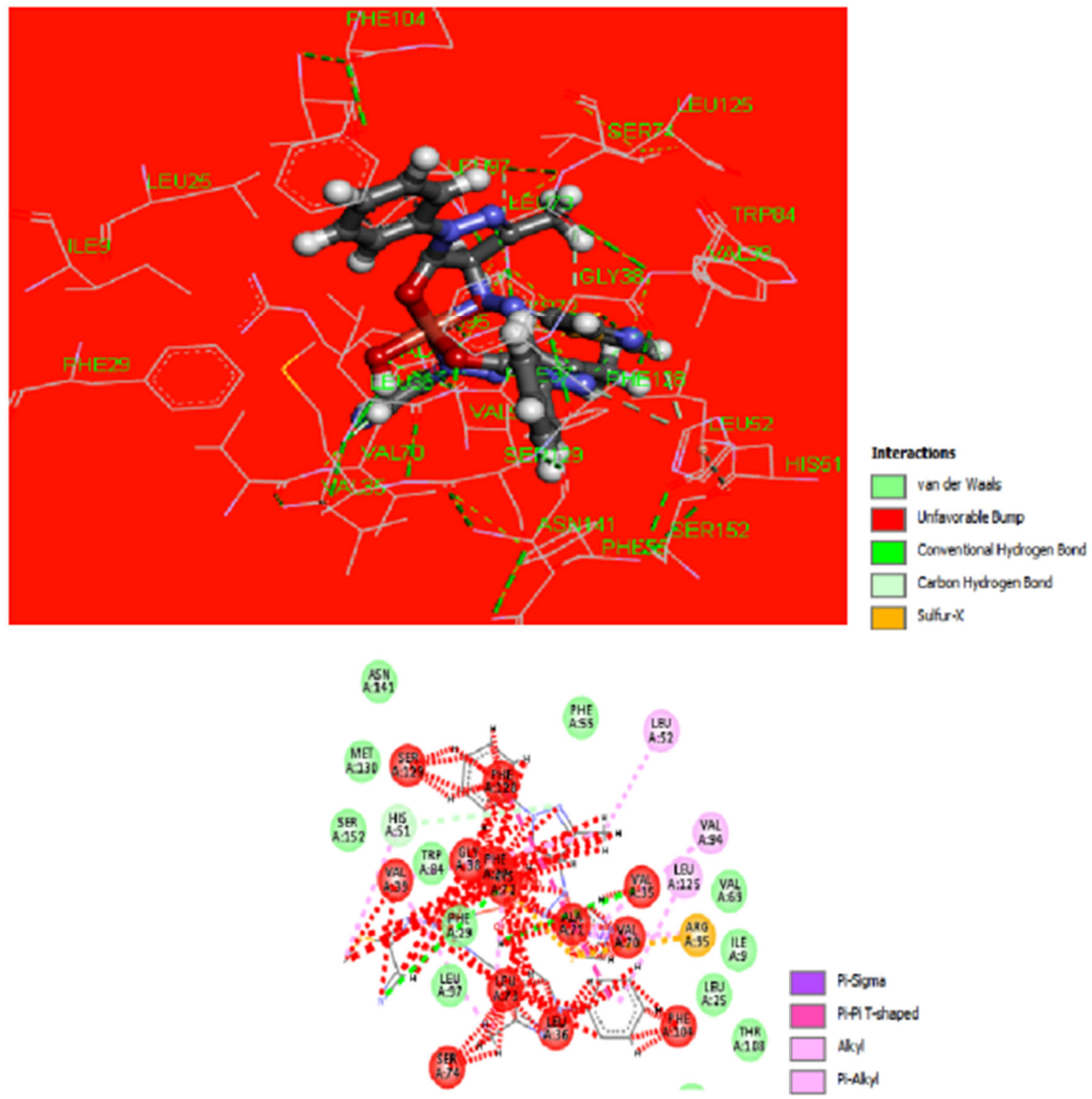

Figure 7: Interaction of 2 with amino acids of 3MNG (top) 3D-structure of complex (ball and stick model Oxygen-red, Nitrogen-blue) protein receptor (stick model) (bottom) 2D-structure of complex.

However, the $3\left(-279 \mathrm{kcal} \mathrm{mol}^{-1}\right)$ and the $4\left(-276.78 \mathrm{kcal} \mathrm{mol}^{-1}\right)$ have good docking energy minimum values than the standard but were not able form good hydrogen bonding interactions with human antioxidant enzyme receptor than $\mathbf{1}$ and $\mathbf{2}$. 

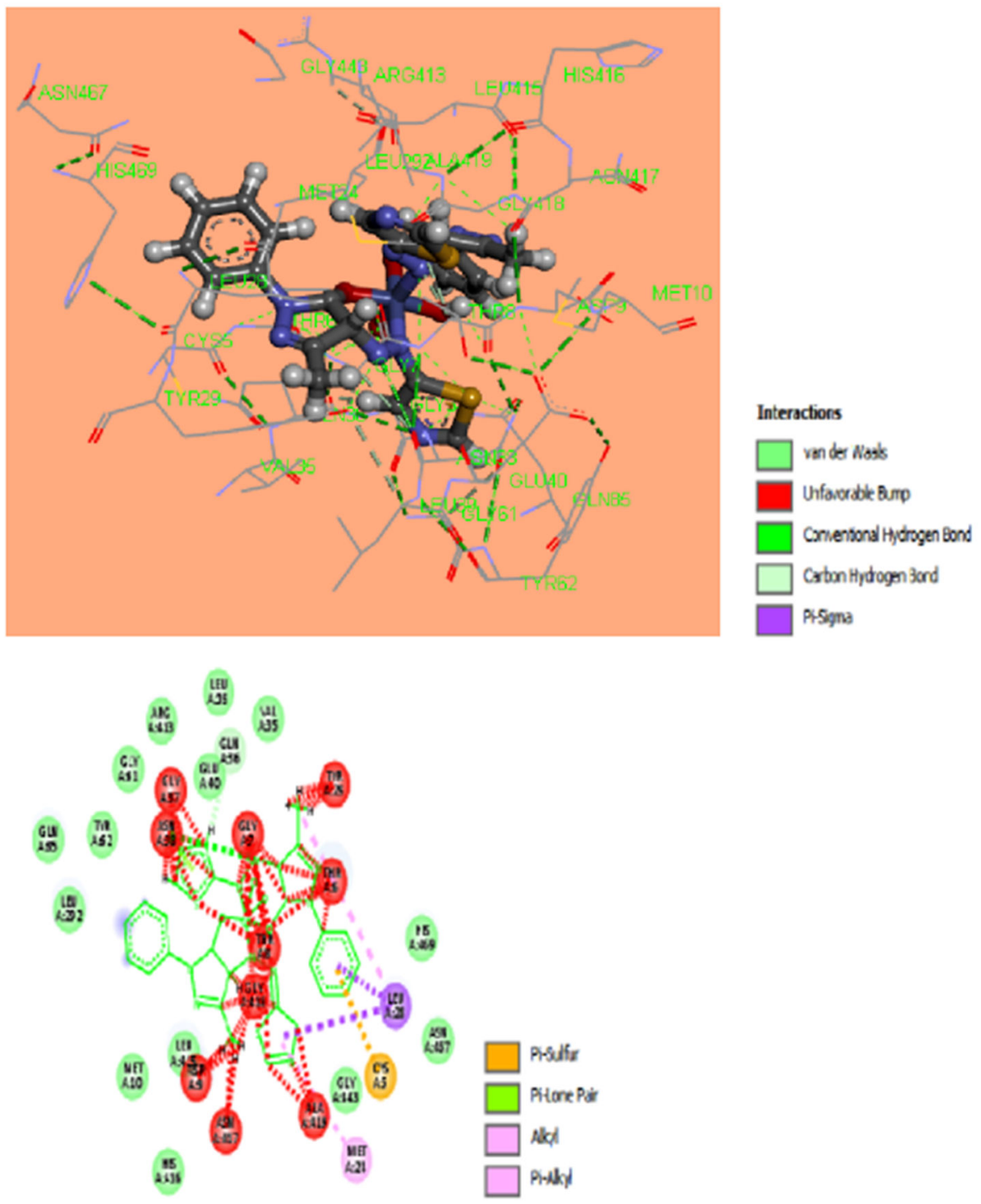

Figure 8: Interaction of 1 with amino acids of 2A91 (top) 3D-structure of complex (ball and stick model Oxygen-red, Nitrogen-blue) protein receptor (stick model) (bottom) 2D-structure of complex. 


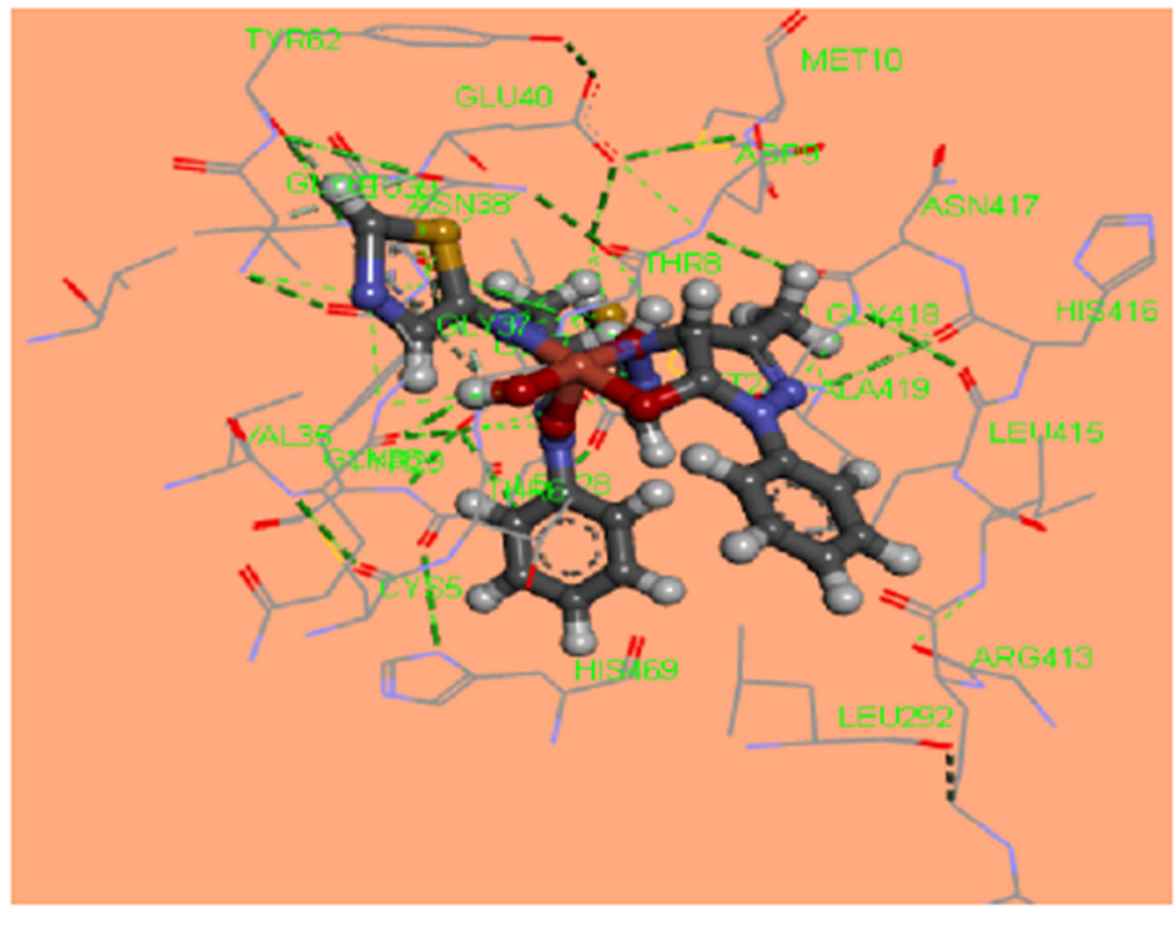

Interactions

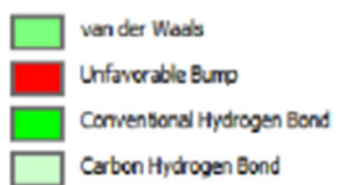

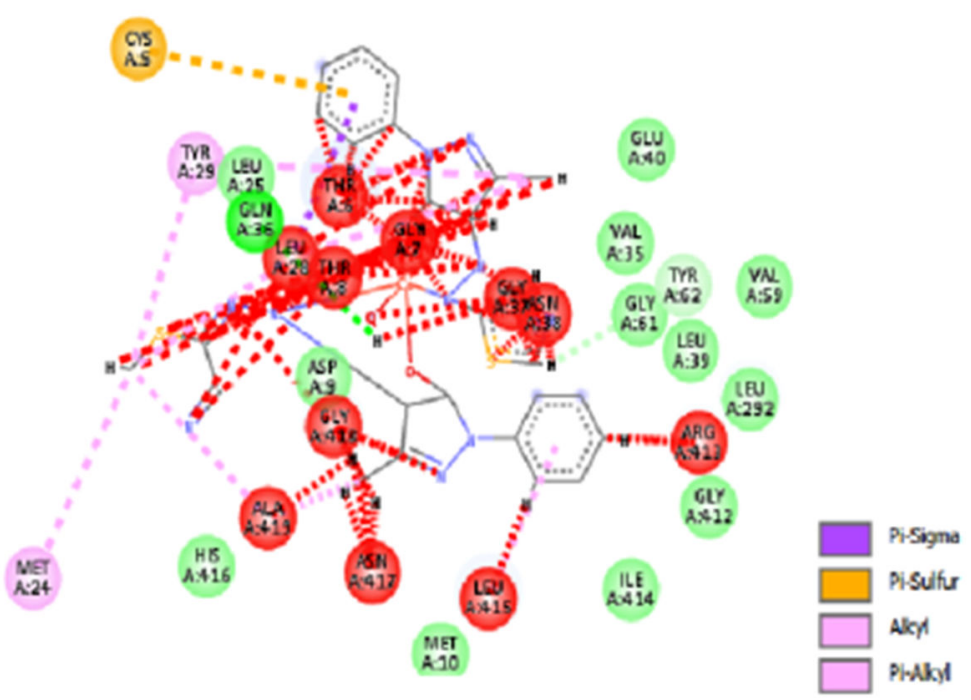

Figure 9: Interaction of 2 with amino acids of 2A91 (top) 3D-structure of complex (ball and stick model Oxygen-red, Nitrogen-blue) protein receptor (stick model) (bottom) 2D-structure of complex.

The EGFR tyrosine kinase was reported several times as target for the inhibition of cancer cells. Therefore all the four complexes used to study the effect docking inside the active site of EGFR kinase domain with a binding energy values in the range of -217.95 to $-323.66 \mathrm{kcal} \mathrm{mol}^{-1}$ as tabulated in Table $5 \mathrm{~b}$. The docking results compared with actinoin drugs for EGFR. The molecular docking results revealed that 1 has the best binding energy value $-323.66 \mathrm{kcal} \mathrm{mol}^{-1}$ for the EGFR kinase domain inhibited complex formation by forming a four hydrogen bond with GLY7 with bond distances $2.988 \AA, 2.838 \AA, 2.656 \AA$ and $2.332 \AA$. Two additional hydrogen bonds formed with amino acids THR 8 and ASN38 with bond distance $3.153 \AA, 2.963 \AA$ and $2.896 \AA$, 
2.330 $\AA$. Single hydrogen bonds were formed between the complex 1 and the amino acids THR6, GLY418 and ALA419 of $2.762 \AA, 3.198 \AA$ and $3.061 \AA$, respectively. The other interacting amino acids were ASN38, THR8 and GLN36 as shown in (Figure 8). The 2 formed two hydrogen bonds with amino acids GLY37 with bond distance $2.955 \mathrm{~A}$ and 2.782 A. A single hydrogen bonds were formed between the 2 and the amino acids ASN38, THR6, LEU39, GLY61, GLY418, ALA419, GLY7 and TYR420 with bond distance $3.193 \AA$, $3.020 \AA, 2.995 \AA, 2.904 \AA 2.577 \AA 2.764 \AA$ and 2.538 $\AA$. The other interacting amino acids were GLN36, ASN38 and TYR62 as shown in Figure 9. Even though the $3\left(-313.42 \mathrm{kcal} \mathrm{mol}^{-1}\right)$ and $4\left(-306.96 \mathrm{kcal} \mathrm{mol}^{-1}\right)$ are having good docking energy values than the standard actinoin $\left(-260.51 \mathrm{kcal} \mathrm{mol}^{-1}\right)$ but these complexes are not forming good hydrogen bonding interactions with EGFR tyrosine kinase receptor than 1 and 2 . The 3 and 4 interaction with active sites of EGFR tyrosine kinase with amino acid residues are LEU415, CYS32, TYR29, CYS5, and LEU28, VAL35, GLU40, ALA419, THR8. The binding value of 1 and 2 showed better cytotoxicity property than the reaming of complexes. The obtained results provide a sufficient explanation and good compromise between docking scores and in-vitro results of antibacterial and cytotoxicity activity.

\section{Cytotoxicity}

The results of cytotoxic activity is tabulated in Table 7 the reliable criteria for judging the efficacy of any anticancer drug are prolongation of life span, improving the clinical, haematological, biochemical profile, and reduction in viable tumor cell count in the host (41). In order to evaluate the biological effects of the ligand, and its $1,2,3$ and 4 on cancer cells to treat human breast cancer (MCF7) and K-562 cell lines at the concentrations of 80,90,100, 110, 120, >130 and $>200 \mu \mathrm{g} / \mathrm{mL}$ for $48 \mathrm{~h}$. The untreated cells were used as control. Cell growth inhibition was analyzed by the MTT assay and the results showed that the complexes and the ligand exhibited an inhibitory effect on the proliferation of MCF7 and K-562 cell lines in a dose-dependent manner. Among them, $\mathbf{1}$ and $\mathbf{2}$ showed the most potent inhibitory effect on the growth of both the MCF7 and K-562 cells lines compared to the uncoordinated ligand.

Table 7: Cytotoxicity activity of ligand and complexes.

\begin{tabular}{llc}
\hline $\begin{array}{l}\text { Tested samples } \\
\text { Ligand }\end{array}$ & \multicolumn{2}{c}{ Inhibitory effect on cell lines $\left(\right.$ IC $\left._{\mathbf{5 0}}\right)$} \\
$\mathbf{M C F - 7}$ & \multicolumn{1}{c}{ K-562 } \\
$\mathbf{1}$ & $>130 \mu \mathrm{g} / \mathrm{mL}(50.38 \%)$ & $>130 \mu \mathrm{g} / \mathrm{mL}(51.02 \%)$ \\
$\mathbf{2}$ & $110 \mu \mathrm{g} / \mathrm{mL}(55.16 \%)$ & $100 \mu \mathrm{g} / \mathrm{mL}(53.42 \%)$ \\
$\mathbf{3}$ & $120 \mu \mathrm{g} / \mathrm{mL}(54.79 \%)$ & $110 \mu \mathrm{g} / \mathrm{mL}(53.23 \%)$ \\
$\mathbf{4}$ & $110 \mu \mathrm{g} / \mathrm{mL}(51.19 \%)$ & $100 \mu \mathrm{g} / \mathrm{mL}(53.36 \%)$ \\
\hline
\end{tabular}

Note. Each value represents mean \pm SD. The data were analyzed by Student's $t$ test. 


\section{CONCLUSION}

New biologically active $\mathrm{Co}(\mathrm{II}), \mathrm{Ni}(\mathrm{II}), \mathrm{Cu}(\mathrm{II})$ and $\mathrm{Zn}$ (II) ion complexes with 5-methyl-2- phenyl4-[(E)-1,3-thiazol-2-yl-diazenyl]-2,4-dihydro-3H-pyrazol-3-one (Dy) are synthesized and structurally characterized. Except the $\mathrm{Zn}(\mathrm{II})$ complex, tentatively octahedral geometry is proposed for the other metal complexes. The newly synthesized $\mathrm{Co}(\mathrm{II})$ and $\mathrm{Cu}$ (II) metal complexes are potent antibacterial and antifungal agents against three bacteria (Salmonella typhi, Staphylococcus aureus, and Escherichia coli) and three fungi (Aspergillus niger, Aspergillus flavus, and Aspergillus fumigates). The synthesized uncoordinated ligand and metal complexes are screened for antioxidant activity, among them, $\mathrm{Cu}$ (II) $\mathrm{Co}$ (II) and $\mathrm{Ni}(\mathrm{II})$ complexes show fairly good activity in DPPH and Nitric Oxide scavenging. The results of computational docking studies promote to evaluate in vitro cytotoxic activity, The $\mathrm{Cu}$ (II) $\mathrm{Co}$ (II) and $\mathrm{Ni}$ (II), complex exhibited more in vitro cytotoxic activity than the unbound ligand and all complexes are of crystalline nature.

\section{REFERENCES}

1. Zollinger H. Azo and Diazo Chemistry, Aliphatic and Aromatic Compounds. New York, USA: Interscience Publishers; 1961. $444 \mathrm{~s}$.

2. Saunders KH, Allen L. Aromatic diazo-compounds and their technical applications. 3rd ed. E. Arnold \& Co. ; 1985.

3. Van Leeuwen PW. Homogeneous catalysis: Understanding the art. Boston: Springer Science \& Business Media; 2006.

4. Clark JH, Rhodes CN. Clean synthesis using porous inorganic solid catalysts and supported reagents. Cambridge: Royal Society of Chemistry; 2000.

5. Smith GV, Notheisz F. Heterogeneous catalysis in organic chemistry. Academic Press; 1999.

6. Hamon F, Djedaini-Pilard F, Barbot F, Len C. Azobenzenes-synthesis and carbohydrate applications. Tetrahedron. 2009;65(49):10105-10123.

7. Waring DR, Hallas G. The chemistry and application of dyes. Springer Science \& Business Media; 2013.

8. Freeman HS, Peters AT. Colorants for non-textile applications. Amsterdam: Elsevier Science BV; 2000.

9. Gregory P. High-technology applications of organic colorants. Plenum Press; 1991.

10. Kubo Y, Maeda S, Tokita S, Kubo M. Colorimetric chiral recognition by a molecular sensor. Nature. Aug 1996;382(6591):522-4.

11. Steinsträsser R, Pohl L. Chemistry and applications of liquid crystals. Angewandte Chemie International Edition. Aug 1973;12(8):617-630.

12. Pieraccini S, Masiero S, Spada GP, Gottarelli G. A new axially-chiral photochemical switch. Chemical Communications. Feb 2003;(5):598-599.

13. Aszalos A, Weaver JL, Pine PS. Methods of using azo dyes and their derivatives. 5,468,469, 1995.

14. Hiremath $S$, Rudresh K, Saundane A. Synthesis and biological activities of new 5-hydrazino-10substituted-7 $\mathrm{H}$-indolo [2, 3-c] isoquinolines and 1-(10-substituted-7H-indolo [2, 3-c] isoquinolin-5-yl)-3, 5-disubstituted pyrazoles,-3-methyl pyrazol-5-ones and-3, 5-disubstituted pyrazolines. Feb 2002;41B(2):394-9.

15. Joerg S, Reinhold G, Otto S, Joachim SH, Robert S, Klaus L, Patent Ger. Offen, 1988 Feb; DE 3, 625, 686 (C1 C07D 231/ 22) [Chem. Abstr. 1988, 108, 167465]

16. Souza FR, Souza VT, Ratzlaff V, Borges LP, Oliveira MR, Bonacorso HG, et al. Hypothermic and antipyretic effects of 3-methyl-and 3-phenyl-5-hydroxy-5-trichloromethyl-4, 5-dihydro-1H-pyrazole-1- 
carboxyamides in mice. European journal of pharmacology. 2002;451(2):141-147.

17. Park H-J, Lee K, Park S-J, Ahn B, Lee J-C, Cho H, et al. Identification of antitumor activity of pyrazole oxime ethers. Bioorganic \& medicinal chemistry letters. 2005;15(13):3307-3312.

18. Clark MP, Laughlin SK, Laufersweiler MJ, Bookland RG, Brugel TA, Golebiowski A, et al. Development of orally bioavailable bicyclic pyrazolones as inhibitors of tumor necrosis factor-a production. Journal of medicinal chemistry. 2004;47(11):2724-2727.

19. Anitha K, Venugopala R, Rao V. , Synthesis and Antimicrobial Evaluation of Metal (II) Complexes of A Novel Bisazo Dye 2, 2 [benzene-13-diyl di (E) diazene 2, 1-diyl] bis (4-chloroaniline). J Chem Pharm Res. $2011 ; 3(3): 511-519$.

20. Vadher GB, Zala RV. Synthesis and analytical studies of some azo dyes as ligands and their metal chelates. International Journal of Chemical Sciences. 2011 Feb;9(1):87-94.

21. Abdallah S. Metal complexes of azo compounds derived from 4-acetamidophenol and substituted aniline. Arabian Journal of Chemistry. 2012 Apr;5(2):251-256.

22. Al-Jibouri MN. Synthesis AND Characterization of transition Metal Complexes With Azo Ligand Derived from 4-Hydroxy-6-Methyl-2-Pyranone. European Chemical Bulletin. 2014 Apr;3(5):447-451.

23. Modhavadiya V. Synthesis, characterization and antimicrobial activity of metal complexes containing azo dye ligand of sulfa drugs. Asian J Bio Chem Pharm Res. 2011;13(4):114-20.

24. Masoud MS, Hagagg SS, Ali AE, Nasr NM. Synthesis and spectroscopic characterization of gallic acid and some of its azo complexes. Journal of Molecular Structure. 2012 Apr;1014:17-25

25. Asiri AM, Khan SA. Palladium (II) complexes of NS donor ligands derived from steroidal thiosemicarbazones as antibacterial agents. Molecules. 2010 Jun;15(7):4784-4791.

26. EI-Sawaf AK, Fatah Nassar AA, EI-S, El-Samanody. Spectral and biological studies of copper (II) complexes of 4-benzoyl-3-methyl-1-phenyl-2 pyrazoline -5-one $\mathrm{N}(4)$-substituted thiosemicarbazones. Science Journal chem. 2014 Aug;2(3);17-26.

27. Rashmi Patel B, Dhanji Rajani P, Hitesh Patel D. Pyrazolone Thiosemicarbazone Based Metal Complexes: Physico-Chemical Study, Synthesis and Biological Activity. J Phys Chem Sci. 2015 Jul;3(2):1-11.

28. Cerchiaro G, Ferreira AMDC, Teixeira AB, Magalhães HM, Cunha AC, Ferreira VF, et al. Synthesis and crystal structure of 2, 4-dihydro-4-[(5-hydroxy-3-methyl-1-phenyl-1H-pyrazol-4-yl) imino]-5-methyl-2phenyl-3H-pyrazol-3-one and its copper (II) complex. Polyhedron. 2006;25(10):2055-2064.

29. Thakar AS, Friedrich HB, Joshi KT, Maguire GE. Isolation, characterization and x-ray structure determination of the schiff base ligand: 5-methyl-2-phenyl-4-[phenyl-(4-phenyl-thiazol-2-ylamino)methylene]-2, 4-dihydro-pyrazol-3-one. South African Journal of Chemistry. 2015;68:39-44.

30. Chukwu U, Godwin J. Solvent extraction studies of Uranium (VI) from aqueous media into chloroform solution of $\mathrm{N}$, N-ethylenebis (4-propionyl-2, 4-dihydro-5-methyl-2-phenyl-3H-pyrazol-3-oneimine). American Chemical Science Journal. 2013;3(4):479-488.

31. Chhowala T, Desai K. Synthesis and studies of eco-friendly acid dye metal complexes and its application on woolen fabrics. IOSR J Appl Chem. 2015 Jan;8:5-10.

32. Galal SA, Hegab KH, Kassab AS, Rodriguez ML, Kerwin SM, Abdel-Mo'men A, et al. New transition metal ion complexes with benzimidazole-5-carboxylic acid hydrazides with antitumor activity. European journal of medicinal chemistry. 2009 Apr;44(4):1500-1508.

33. Rahimizadeh M, Eshghi H, Shiri A, Ghadamyari Z, Matin MM, Oroojalian F, et al. Fe (HSO4) 3 as an Efficient Catalyst for Diazotization and Diazo Coupling Reactions. Journal of the Korean Chemical Society. 2012 Oct;56(6):716-719.

34. Krishnamurthy G. Synthesis, Molecular Modeling, and Biological Activity of Zinc (II) Salts with 1, 4Bis (benzimidazol-2-yl) benzene. Journal of Chemistry. 2012;2013:1-7.

35. Gajanan H., Shivarudrappa H. P., Yallappa S, Venkatesh T, Nagendra S.Y., B. Bharath Raj. R. Mohammed Shafeeulla, B. L Dhananjaya. Synthesis And Characterization Of Novel PyridinimineBased Schiff Base Ligands And Their Cu (Ii) Complexes For Biomedical Applications. Wjpr. 2016 Sep;5(9);715-29

36. Bhat M, G. K. N, Kayarmar R, S. K. P, R MS. Design, synthesis and characterization of new 1,2,3triazolyl pyrazole derivatives as potential antimicrobial agents via a Vilsmeier-Haack reaction approach. RSC Adv. 2016 Jun;6(64):59375-88.

37 Dharshan JC, Vishnumurthy KA, Bodke YD, Jayanna ND, Mohammed Shafeeulla R. 
Synthesis, Evaluation and Molecular Docking Studies of SomeNovel Pyrazolo[3,4-d]pyrimidine Derivatives of 7-Methoxy Quinoline. Asian. J. Org \& Med Chem.2016 May;1(1);10-16

38. Ashraf A, Siddiqui WA, Akbar J, Mustafa G, Krautscheid H, Ullah N, et al. Metal complexes of benzimidazole derived sulfonamide: Synthesis, molecular structures and antimicrobial activity. Inorganica Chimica Acta. 2016 Mar;443:179-185.

39. Patil BS, Krishnamurthy G, Shashikumar N, Lokesh M, Bhojya Naik H. Synthesis and antimicrobial activity of some [1, 2, 4]-triazole derivatives. Journal of Chemistry. 2012 Sep;2013.

40. Patil BS, Krishnamurthy G, Lokesh M, Shashikumar N, Naik HB, Latthe PR, et al. Synthesis of some novel 1, 2, 4-triazole and 1, 3, 4-oxadiazole derivatives of biological interest. Medicinal Chemistry Research. 2013 Nov;22(7):3341-3349.

41. Williams DH, Fleming I. Spectroscopic methods in organic chemistry. London, New York: McGraw-Hill; 1973.

42. Nakamoto K. Infrared spectra of inorganic and coordination compounds. New York: John Wiley; 1970.

43. Bottino F, Finocchiaro P, Libertini E. Synthesis and characterization of schiff base complexes with zinc halides. Journal of coordination chemistry. 1988 May;16(4):341-345.

44. Gluvchinsky P, Mockler GM, Sinn E. Nickel (II) complexes of some quadridentate Schiff-base ligandsII. Infrared spectra. Spectrochimica Acta Part A: Molecular Spectroscopy. 1977;33(12):1073-1077.

45. Sridharan K. Spectral Methods in Transition Metal Complexes. 1st edition. Elsevier; 2016.

46. Bartlett J, Brawley D, Grigor K, Munro AF, Dunne B, Edwards J. Type I receptor tyrosine kinases are associated with hormone escape in prostate cancer. The Journal of pathology. 2005 Mar;205(4):522529.

47. Alaghaz A-NM, Bayoumi HA, Ammar YA, Aldhlmani SA. Synthesis, characterization, and antipathogenic studies of some transition metal complexes with N, O-chelating Schiff's base ligand incorporating azo and sulfonamide Moieties. Journal of Molecular Structure. 2013 Mar;1035:383-399.

48. Abd-Elzaher MM, El-shiekh SM, Eweis M. Biological studies of newly synthesized ferrocenyl complexes containing triazinone moiety. Applied organometallic chemistry. 2006 Oct;20(10):597-602.

49. El-shiekh SM, Abd-Elzaher MM, Eweis M. Synthesis, characterization and biocidal studies of new ferrocenyl thiadiazolo-triazinone complexes. Applied organometallic chemistry. 2006 Aug;20(8):505-511.

50. Erdem E, Sari EY, Kilinçarslan R, Kabay N. Synthesis and characterization of azo-linked Schiff bases and their nickel (II), copper (II), and zinc (II) complexes. Transition metal chemistry. 2009 Mar;34(2):167-174.

51. Yousef T, El-Reash GA, El-Gammal O, Bedier R. Synthesis, characterization, optical band gap, in vitro antimicrobial activity and DNA cleavage studies of some metal complexes of pyridyl thiosemicarbazone. Journal of Molecular Structure. 2013 May;1035:307-317.

52. Warren B. X Ray Diffraction. 2nd edition. New York: Dover Books; 1990. 
Shafeeulla R, Krishnamurthy, Bhojynaik, Manjuraj, JOTCSA. 2017; 4(3): 787-810. RESEARCH ARTICLE 